\title{
IPTEKS PENYUSUNAN LAPORAN REALISASI ANGGARAN PADA KANTOR PENGAWASAN DAN PELAYANAN BEA DAN CUKAI TIPE MADYA PABEAN C MANADO
}

\author{
Kirana Falerina Mamuaja \\ Jurusan Akuntansi, Fakultas Ekonomi dan Bisnis, Universitas Sam Ratulangi, Jl. Kampus Unsrat, Sulawesi \\ Utara, 95115, Indonesia \\ E-mail: kirana.mamuaja@gmail.com
}

\begin{abstract}
Budget Realization Report is one component of the government financial statements that presents information about the realization and budget reporting entities in an equal manner for a certain period. Budget Realization Reports can provide information to report users about the indication of the acquisition and use of economic resources that have been carried out efficiently, effectively, accountably, and have been carried out in accordance with the budget and in accordance with statutory regulations. Customs and Excise has duties and functions that are closely related to the management of state finances. Customs and Excise manages state finances and carries out state revenue through import duties and excise. As a government agency that deals directly with export and import activities, Customs and Excise continues to strive to create various facilities in order to boost the pace of the Indonesian economy.
\end{abstract}

Keywords: budget realization report, income-LRA, customs and excise

\section{PENDAHULUAN}

Perkembangan ilmu pengetahuan dan teknologi sekarang ini berkembang sangat pesat. Hal itu berpengaruh pada pertumbuhan ekonomi juga mengalami peningkatan. Untuk mencapai good governance dalam tata pemerintahan Indonesia, maka prinsip-prinsip good governance hendaknya ditegakkan dalam berbagai institusi penting pemerintahan. Tuntutan demokrasi ini menyebabkan aspek transparansi dan akuntabilitas menjadi hal penting dalam pengelolaan pemerintah termasuk dalam Laporan Realisasi Anggaran. Adanya tuntutan masyarakat akan transparansi dan akuntabilitas, memaksa pemerintah baik pusat maupun daerah untuk menciptakan sistem Laporan Realisasi Anggaran yang lebih transparan dan akuntabel. Sistem ini diharapkan dapat mewujudkan Laporan Realisasi Anggaran secara tertib, taat pada peraturan perundang-undangan, efisien, ekonomis, efektif, transparan, dan bertanggung jawab dengan memperhatikan keadilan, kepatuhan dan manfaat untuk masyarakat.

Pendapatan terbesar Indonesia berasal dari bea masuk dan cukai yang ditangani langsung oleh Bea dan Cukai. Instansi pemerintah ini memiliki tugas dan fungsi yang berkaitan erat dengan pengelolaan keuangan negara yang di dalamnya terdapat Laporan Realisasi Anggaran. Pengelolaan keuangan yang ada di instansi ini sangatlah penting untuk dilakukan secara akuntabilitas dan transparansi. Untuk memberikan informasi tentang realisasi dan anggaran entitas pelaporan secara tersanding. Penandingan antara anggaran dan realisasinya menunjukkan tingkat ketercapaian target-target yang telah disepakati antara legislatif dan eksekutif sesuai dengan peraturan perundang-undangan, namun masih terdapat beberapa kendala terkait hambatan realisasi anggaran seperti penumpukan realisasi anggaran pada akhir tahun dan tidak tidak adanya komponen atau unsur-unsur yang diwajibkan Standar Akuntansi Pemerintahan (Woinalang et al., 2016; Rombebunga et al., 2018). Kinerja dalam 
merealisasikan anggaran pendapatan dan belanja jika dilakukan dengan baik dan benar maka akan menghasilkan penerimaan negara yang optimal.

\section{TINJAUAN PUSTAKA}

Akuntansi. Menurut Rudianto (2010:10), Akuntansi adalah aktivitas mengumpulkan, menganalisis, menyajikan dalam bentuk angka, mengklasifikasikan, mencatat, meringkas, dan melaporkan aktivitas/transaksi suatu badan usaha dalam bentuk informasi keuangan.

Sistem Akuntansi Pemerintah Pusat. Dalam Peraturan Menteri Keuangan Nomor 262/PMK.05/2014, Sistem Akuntansi dan Pelaporan Keuangan Pusat (SiAP) adalah serangkaian prosedur manual maupun yang terkomputerisasi mulai dari pengumpulan data, pencatatan, pengiktisaran sampai dengan pelaporan posisi keuangan, dan operasi keuangan pada kementrian keuangan selaku BUN (Bendahara Umum Negara). Semua penerimaan dan pengeluaran negara dilakukan melalui rekening kas umum negara. Menurut Undang-Undang No. 1 Tahun 2004 pasal 12 ayat 2, tahun anggaran adalah periode pelaksanaan APBN selama 12 bulan. Sejak tahun 2000, Indonesia mennggunakan tahun kalender sebagai tahun anggaran, yaitu dari tanggal 1 Januari sampai dengan 31 Desember. Sebelumnya tahun anggaran dimulai tanggal 1 April sampai dengan 31 Maret tahun berikutnya. Penggunaan tahun kalender sebagai tahun anggaran ini kemudian dikukuhkan dalam UU Keuangan Negara dan UU Perbendaharaan Negara (Pasal 4 UU No. 17 Tahun 2003 dan Pasal 11 UU No. 1 Tahun 2004).

Anggaran Pendapatan dan Belanja Negara (APBN). Anggaran Pendapatan dan Belanja Negara APBN adalah rencana keuangan tahunan pemerintah negara yang disetujui oleh Dewan Perwakilan Rakyat (Undang-Undang No. 17 Tahun 2003, pasal 1 angka 7,). Merujuk Undang-Undang No. 1 Tahun 2004 pasal 12 tentang Perbendaharaan Negara, APBN dalam satu tahun anggaran meliputi: (a) hak pemerintah pusat yang diakui sebagai penambah nilai kekayaan; (b) kewajiban pemerintah pusat yang diakui sebagai pengurang nilai kekayaan; dan (c) penerimaan yang perlu dibayar kembali dan atau pengeluaran yang akan diterima kembali, baik pada tahun anggaran yang bersangkutan maupun pada tahun-tahun anggaran berikutnya.

Anggaran. Anggaran dapat dianggap sebagai alat pengendali untuk membandingkan sampai sejauh mana hasil yang dicapai dengan rencana yang telah dicapai. Disamping itu anggaran merupakan hal yang dicapai. Disamping itu anggaran merupakan hal penting bagi Pemerintahan karena menjadi dasar pelaksanaan kegiatan. Menurut Munandar (2004:3) dalam bukunya Budgeting yang mendefenisikan anggaran adalah sebagai berikut: Anggaran adalah suatu rencana yang disusun secara sistematis yang meliputi seluruh kegiatan perusahaan yang dinyatakan dalam unit (kesatuan) moneter dan berlaku untuk jangka waktu (periode) tertentu yang akan datang.

Laporan Realisasi Anggaran (LRA). Laporan Realisasi Anggaran merupakan salah satu komponen laporan keuangan pemerintah yang menyajikan informasi tentang realisasi dan anggaran entitas pelaporan secara tersanding untuk suatu periode tertentu. Informasi tersebut berguna bagi para pengguna laporan dalam mengevaluasi keputusan mengenai alokasi sumber daya ekonomi, akuntabilitas, dan ketaatan entitas pelaporan terhadap anggaran (Halim dan Kusufi, 2012: 284). Menurut Santje et al. (2015) Laporan Realisasi Anggaran juga menyajikan ikhtisar sumber, alokasi dan penggunaan sumber daya ekonomi yang dikelola oleh pemerintah pusat/daerah dalam satu periode pelaporan. Perbandingan antara anggaran dan realisasinya menunjukkan tingkat ketercapaian target-target yang telah disepakati antara legislatif dan eksekutif sesuai dengan peraturan perundang-undangan.

Ketepatan Waktu Pelaporan. Ketetepatan waktu merupakan hal yang harus diperhatikan sekali dalam pelaporan keuangan, karena dapat mengefisiensi waktu 
pengambilan keputusan berdasarkan hasil pelaporan keuangan, semesteran atau laporan keuangan tahunan.

Periode Pelaporan Realisasi Anggaran. Laporan Realisasi Anggaran (LRA) disajikan sekurang-kurangnya sekali dalam setahun.Selain itu Laporan Realisasi Anggaran ini juga disajikan 2 kali setahun, yaitu laporan semesteran dan laporan tahunan. Dalam situasi tertentu, tanggal laporan suatu entitas berubah dan Laporan Realisasi Anggaran (LRA) tahunan disajikan dengan satu periode yang berubah lebih panjang atau pendek dari satu tahun, entitas mengungkapkan informasi anggaran alasan penggunaan periode pelaporan tidak satu tahun dan fakta bahwa jumlah-jumlah komparatif dalam Laporan Realisasi Anggaran dalam catatan-catatan terkait tidak dapat diperbandingkan.

Siklus Anggaran. Siklus Anggaran atau budget cycle adalah masa atau jangka waktu mulai saat anggaran (APBN) disusun sampai dengan saat perhitungan anggaran disahkan dengan undang-undang. Siklus anggaran terdiri atas penyusunan anggaran, pelaksanaan anggaran, pengawasan anggaran, dan pelaporan dan pertanggungjawaban anggaran. Penyusunan rencana kerja mengacu kepada Peraturan Pemerintah Nomor 20 Tahun 2004 tentang Rencana Kerja Pemerintah dan Peraturan Pemerintah Nomor 21 Tahun 2004 tentang RKA-KL.

Tujuan Laporan Realisasi Anggaran (LRA). Tujuan Laporan Realisasi Anggaran adalah menetapkan dasar-dasar Penyajian Laporan Realisasi Anggaran untuk pemerintah dalam rangka memenuhi tujuan akuntabilitas sebagaimana oleh peraturan perundang undangan. Jadi untuk memberikan informasi tentang realisasi dan anggaran entitas pelaporan secara tersanding. Penyandingan antara anggaran dan realisasinya menunjukkan tingkat ketercapaian target-target yang telah disepakati antara legislatif dan eksekutif sesuai dengan peraturan perundang-undangan.

Manfaat Laporan Realisasi Anggaran. Berdasarkan Peraturan Pemerintah No. 71 tahun 2010 tentang Standar Akuntansi Pemerintah yang disajikan berdasarkan PSAP No.02 tentang Laporan Realisasi Anggaran, dalam laporan realisasi anggaran akan menyediakan informasi mengenai realisasi pendapatan, belanja, transfer, surplus atau defisit dan pembiayaan dari suatu entitas pelaporan. Informasi tersebut berguna bagi para pengguna laporan dalam mengevaluasi keputusan mengenai alokasi sumber-sumber daya ekonomi, akuntabilitas dan ketaatan entitas pelaporan terhadap anggaran dengan:

1. Menyediakan informasi mengenai sumber, alokasi, dan penggunaan sumber daya ekonomi.

2. Menyediakan informasi mengenai realisasi anggaran secara menyeluruh yang berguna dalam mengevaluasi kinerja pemerintah dalam hal efisiensi dan efektivitas penggunaan anggaran.

3. Laporan Realisasi Anggaran menyediakan informasi yang berguna dalam memprediksi sumber daya ekonomi yang akan diterima untuk mendanai kegiatan pemerintah pusat dan daerah dalam periode mendatang dengan cara menyajikan laporan secara komparatif.

4. Laporan Realisasi Anggaran dapat menyediakan informasi kepada para pengguna laporan tentang indikasi perolehan dan penggunaan sumber daya ekonomi: (a) telah dilaksanakan secara efisien, efektif, dan hemat; (b) telah dilaksanakan sesuai dengan anggarannya (APBN/APBD); dan (c) telah dilaksanakan sesuai dengan peraturan perundang-undangan.

\section{METODE DAN TEKNIK PENERAPAN IPTEKS}

Metode yang digunakan dalam penerapan ipteks adalah membandingkan Pernyataan Standar Akuntansi Pemerintahan No 02 pada penyusunan laporan realisasi anggaran dengan penerapan penyusunan laporan realisasi anggaran pada Kantor Pengawasan dan Pelayanan Bea dan Cukai Tipe Madya Pabean $\mathrm{C}$ Manado. Teknik yang digunakan dalam penerapan ipteks yaitu menganalisa dan melakukan penelitian pada laporan realisasi anggaran pada 
Kantor Pengawasan dan Pelayanan Bea dan Cukai Tipe Madya Pabean C Manado apakah sudah sesuai dengan Pernyataan Standar Akuntansi Pemerintahan No 02 tentang laporan realisasi anggaran mengenai perbandingan dan selisih antara anggaran-anggaran yang telah ditetapkan oleh pemerintah dengan anggaran yang terealisasi. Untuk mengukur kinerja suatu anggaran dapat digunakan teori efektifitas anggaran. Berikut ini adalah teori efektifitas dengan mengguanakan analisis variasi (selisih) yaitu:

$$
\text { Efektifitas }=\frac{\text { Realisasi }}{\text { Anggaran }} \times 100 \%
$$

Untuk menghitung presentase jawaban yang diperoleh dengan menggunakan rumus Dean J. Champion, sebagai berikut:

1. $0 \%-25 \%$ : berarti penerapan PSAP Nomor 02 tidak baik.

2. $25 \%-50 \%$ : berarti penerapan PSAP Nomor 02 kurang baik.

3. $50 \%-75 \%$ : berarti penerapan PSAP Nomor 02 cukup baik.

4. $75 \%-100 \%$ : berarti penerapan PSAP Nomor 02 sangat baik.

\section{PEMBAHASAN}

\subsection{Gambaran objek penerapan ipteks}

Kantor Pengawasan dan Pelayanan Bea dan Cukai Tipe Madya Pabean C Manado berlokasi di Jl. A. A. Maramis, Paniki Bawah, Mapanget, Kota Manado, Provinsi Sulawesi Utara. Kantor Pengawasan dan Pelayanan Bea dan Cukai Tipe Madya Pabean C Manado mempunyai visi "Menjadi institusi kepabeanan dan cukai terkemuka di dunia". Dengan misi "Menjadi fasilitator perdagangan dan industri; Menjaga perbatasan dan melindungi masyarakat Indonesia dari penyelundupan dan perdagangan ilegal khususnya di wilayah Sulawesi Utara; Mengoptimalkan penerimaan negara di Sektor Kepabenan dan Cukai. Kantor Pengawasan dan Pelayanan Bea dan Cukai Tipe Madya Pabean C Manado mempunyai komitmen untuk memberikan pelayanan yang prima dan pengawasan yang efektif kepada pengguna jasa kepabeanan dan cukai dengan melaksanakan cara kerja yang cepat, efisiensi, tranparan, dan responsif terhadap kebutuhan pengguna jasa dengan dukungan instansi teknis terkait. Untuk mengoptimalkan fungsi Direktorat Jenderal Bea dan Cukai, Kantor Pengawasan dan Pelayanan Bea dan Cukai Tipe Madya Pabean C Manado mengemban amanah untuk menjadi kantor pelayanan yang bebas korupsi, kolusi, dan nepotisme yang didukung dengan sarana dan prasarana yang memadai dan sumber daya manusia yang berintegritas tinggi, professional, sinergi, pelayanan, dan kesempurnaan. Kantor Pengawasan dan Pelayanan Bea dan Cukai Tipe Madya Pabean C Manado memiliki 5 seksi, Sub Bagian Umum, Seksi Penindakan dan Penyidikan, Seksi Perbendaharaan, Seksi Pelayanan Kepabeanan dan Cukai dan Dukungan Teknis, Seksi Kepatuhan Internal dan Penyelundupan. Wilayah pengawasan dan pelayanan Kantor Pengawasan Dan Pelayanan Bea Dan Cukai Tipe Madya Pabean C Manado: Kota Manado, Kab. Minahasa Utara, Kab. Minahasa, Kota Tomohon, Kota Kotamobagu, Kab. Bolaang Mongondow, Kab. Bolmong Selatan, Kab. Bolmong Utara, Kab. Kepulauan Sitaro, Kab. Kepulauan Sangihe, Kab. Talaud. Kantor Pengawasan Dan Pelayanan Bea Dan Cukai Tipe Madya Pabean C Manado memiliki 5 Kantor Bantu Pelayanan dan 4 Pos Pengawasan dalam wilayah kerjanya, yakni: (1) Kantor Bantu Labuan Uki, (2) Kantor Bantu Tahuna, (3) Kantor Bantu Hulu Siau, (4) Kantor Bantu Miangas, (5) Kantor Bantu Lirung, (6) Pos Sam Ratulangi, (7) Pos Inobonto, (8) Pos Molibagu, (9) Pos Tagolandang.

\subsection{Isi Laporan Realisasi Anggaran}

Laporan Realisasi Anggaran sekurang-kurangnya mencakup pos-pos sebagai berikut:

1. Pendapatan. Semua penerimaan Rekening Kas Umum Negara/Daerah yang menambah 
saldo anggaran lebih dalam periode tahun anggaran yang bersangkutan yang menjadi hak pemerintah, dan tidak perlu dibayar kembali oleh Pemerintah.

2. Belanja. Semua pengeluaran dari Rekening Kas Umum Negara/Daerah yang mengurangi saldo anggaran lebih dalam periode tahun anggaran bersangkutan yang tidak akan diperoleh pembayarannya kembali oleh pemerintah.

3. Transfer. Penerimaan/pengeluaran uang dari suatu entitas pelaporan dari/kepada entitas pelaporan lain, termasuk dana perimbangan dan dana bagi hasil.

4. Surplus atau Defisit. Selisih lebih/kurang antara pendapatan LRA dan belanja selama satu periode pelaporan dicatat dalam pos Surplus/Defisit LRA.

5. Penerimaan Pembiayaan. Semua penerimaan Rekening Kas Umum Negara/Daerah antara lain berasal dari penerimaan pinjaman, penjualan obligasi pemerintah, hasil privatisasi perusahaan negara/daerah, penerimaan kembali pinjaman yang diberikan kepada pihak ketiga, penjualan investasi permanen lainnya, dan pencairan dana cadangan.

6. Pengeluaran Pembiayaan. Semua Pengeluaran Rekening Kas Umum Negara/Daerah antara lain pemberian pinjaman kepada pihak ketiga, penyertaan modal pemerintah, pembayaran kembali pokok pinjaman dalam periode tahun anggaran tertentu, dan pembentukan dana cadangan.

7. Pembiayaan Neto. Selisih antara penerimaan pembiayaan setelah dikurangi pengeluaran pembiayaan dalam periode tahun anggaran tertentu.

8. Sisa Lebih/Kurang Pembiayaan Anggaran. Sisa lebih/kurang antara realisasi penerimaan dan pengeluaran selama satu periode pelaporan.

\section{KESIMPULAN DAN SARAN}

Kantor Pengawasan dan Pelayanan Bea dan Cukai Tipe Madya Pabean C Manado telah menerapkan Laporan Realisasi Anggaran yang berdasarkan pada pos-pos yang ada dalam Pernyataan Standar Akuntansi Pemerintahan No 02 Tentang Laporan Realisasi Anggaran.

\section{DAFTAR PUSTAKA}

Admin Web Bea dan Cukai. (2011). Sekilas Direktorat Jenderal Bea Dan Cukai. www.beacukai.go.id/arsip/abt/sejarah-bea-dan-cukai.html

Admin Web Bea dan Cukai. (2011). Visi, Misi dan Fungsi Utama. www.beacukai.go.id/arsip/abt/visi-misi-dan-fungsi-utama.html

Admin Web Bea dan Cukai. (2012). Struktur Organisasi. www.beacukai.go.id/arsip/abt/struktur-organisasi.html

Bcmanado. Profil Bea Cukai Manado. https://bcmanado.com/profil/

Halim, A., \& Kusufi M. S. (2012). Akuntansi sektor publik: Akuntansi keuangan daerah, Edisi 4. Jakarta: Salemba Empat.

Kementrian Keuangan. Peranan Bea Cukai Bagi Indonesia. Direktorat Jenderal Bea dan Cukai. https://www.beacukai.go.id/berita/peranan-bea-cukai-bagi-indonesia.html

Munandar. (2004). Budgeting Perencanaan Kerja Pengkoordinasian Kerja Pengawasan Kerja. Yogyakarta: BPFE Yogyakarta.

Peraturan Menteri Keuangan Nomor 262/PMK.05/2014 tentang Sistem Akuntansi Dan Pelaporan Keuangan Pemerintah Pusat.

Peraturan Pemerintah Republik Indonesia Nomor 20 Tahun 2004 tentang Rencana Kerja Pemerintah.

Peraturan Pemerintah Republik Indonesia Nomor 21 Tahun 2004 tentang Penyusunan Rencana Kerja dan Anggaran Kementerian Negara/Lembaga. 
Peraturan Pemerintah Republik Indonesia Nomor 71 Tahun 2010 tentang Standar Akuntansi Pemerintah.

Rombebunga, F., Saerang, D. P. E., \& Budiarso, N. S. (2018). Evaluasi penyajian laporan keuangan Dinas Pekerjaan Umum Kota Bitung berdasarkan penerapan Peraturan Pemerintah No. 71 tahun 2010. Jurnal Riset Akuntansi Going Concern, 13(4), 295301. https://doi.org/10.32400/gc.13.04.21104.2018

Rudianto. (2010). Akuntansi Koperasi. Edisi ke-2. Jakarta: Penerbit Erlangga.

Santje, E. J. G., Jantje, J. T., \& Lidia, M. M. (2015). Analisis penyajian laporan realisasi anggaran pada Dinas Energi dan Sumber Daya Mineral Provinsi Sulawesi Utara. Jurnal EMBA: Jurnal Riset Ekonomi, Manajemen, Bisnis dan Akuntansi, 3(2), 852862. https://ejournal.unsrat.ac.id/index.php/emba/article/view/8908

Undang-Undang Nomor 17 Tahun 2003 tentang Keuangan Negara.

Undang-Undang Nomor 1 Tahun 2004 tentang Perbendaharaan Negara.

Woinalang, A., Sondakh, J., \& Ilat, V. (2016). Faktor-faktor yang berpengaruh terhadap Anggaran Pendapatan dan Belanja Daerah (APBD) berbasis kinerja pada Pemerintah Kota Bitung Provinsi Sulawesi Utara. Jurnal Accountability, 5(2), 110 118. https://doi.org/10.32400/ja.14429.5.2.2016.110-118 